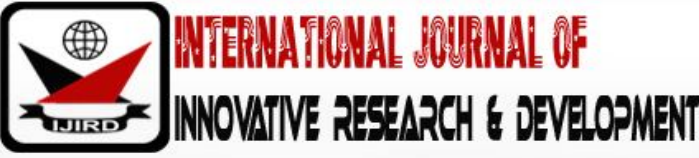

ISSN 2278 - 0211 (Online)

\section{Competencies in Knowledge, Preparation and Questioning Skills: From English Teachers' Perspectives}

\author{
Supriusman \\ Faculty of Education, National University of Malaysia, Malaysia \\ Melor Md Yunus \\ Faculty of Education, National University of Malaysia, Malaysia \\ Mohd Hanafi Mohd Yasin \\ Faculty of Education, National University of Malaysia, Malaysia
}

\begin{abstract}
:
This survey study aims to identify English teachers' competencies in their knowledge, preparation and questioning skills in enhancing students' English proficiency. The aspects of teachers' knowledge in this study focuses on their knowledge in difficulty level of questions, questioning strategies suitable for students' needs. Meanwhile, for their preparation more refer to types of questions and materials that can improve English learning in the classrooms. As for questioning skills, the aspects are viewed from teachers' variety skills such as designing the questions as well as differentiating higher and lower order level of questions. This study involved 160 English teachers from 40 junior high schools in Pekanbaru, Riau Indonesia.the pilot study test using Cronbach Alpha analysis revealed that all items in the constructs between 0.772 and 0.962 . data were analyzed using SPSS 22.0. The results show that the overall level of knowledge is moderate except for knowledge on promoting students' thinking to guide them in answering the questions which is at high level. As for the preparation, results show that the overall level is high and this shows that teachers often prepared prior to English lessons. Questioning skills level reported to be at moderate level in which illustrates that teachers are yet to master the skills acquired in questioning. The implication of this study reveals that all of the three aspects are crucial in improving the students' English proficiency and need to be mastered by the English teachers.
\end{abstract}

Keywords: English teachers, knowledge, preparation, questioning skills

\section{Introduction}

Education in the 21st century requires more creativity in a diverse approach to teaching and learning process. Today's information, communication, and technology (ICT) allow students to gain the latest information very quickly. Hence, teachers should be well positioned in providing themselves with an extensive preparation both in terms of knowledge and skills to meet the standard requirement for their students today. Conventional strategic approach and method such as the traditional teaching technique were proven to be unbefitting toward students' needs. Thus, teaching and learning techniques should be improvised and given an innovative dimension, especially inside the classroom (Luaran, 2013).

\section{Literature Review}

The importance of questioning strategies in teaching a language is not a new thing as their creativity and initiatives to diversify their teaching strategies become one of the most influential factors in determining the success of the students. Teachers play an imperative role to deliver the lesson and to ensure that the students would have high confidence and motivation. This is in line with a study by Amran (2003) which stated that the awareness of the importance of English language will promote positive behavior among students. This situation would further encourage them to some extent willing to spend their own money to buy learning support in preparation for their future career.

A study in the past revealed that teachers' competence in teaching English affect students' abilities in using English language (Souriyavongsa et.al 2013). Effectives multiple questioning strategies (MQS) implementation in schools is depending on teachers kills in questioning strategies. Souriyavongsa et.al (2013) stated that teachers who are not well-trained in questioning strategies will not attract the students' interest and will eventually lead to weak student performance in English. 
An excellent teaching session should include the teacher skill in suitably using the teaching method as well as according to the students' learning objective and learning style (Hashim \&Yaakub 2003).

The importance of MQS implementation for teaching foreign language has been widely discussed. Rashid \& Qaisar (2017) noted that English language has been used for transferring the Western ideology and culture for teaching and learning English in various countries. This highlights the importance of social cultural elements while teaching English. Ariffin (2005) supported that the importance of MQS implementation in teaching English due to abundance English references. Past studies found that failure in English command will lead to the students' inabilities to be employed, continuing their studies, as well as involving with professional work which makes is imperative for people to learn in understanding this language (Rabey, 2001).

In teaching English, the use of questions in classroom should relate with the context of the country. Some countries believe that the integration of English language in their country is a form of neo-colonialism. Libya, for example, is one of the countries with a strong attachment to its native language and thus the introduction of English language in this country in an arduous task. In addition, the poor motivation and negative attitudes towards the learning of English language also contribute to poor acceptance of English. As discussed earlier, motivation is a fundamental core in learning a language and thus with lack of motivation, the mastery of this language is an impossible task. Unless total motivation and positive behavior among the students and the teachers can be established in these countries, the generations with English proficiency will not be achieved (Awad 2012). In order to motivate students to learn English, teachers' abilities in using MQS is vital.

\subsection{Problem Statement}

Research on questioning strategies in teaching and learning is extensively conducted abroad, especially in the developed countries. Robitaille and Maldonado (2015), for example, carried out a study on the relationship between questioning techniques used by teachers in teaching and learning process, and students' participation in the activity. However, many types of research mainly focus on students' responses from oral questions without observing the comprehensive strategies used for questioning. The comprehensive questioning strategy is related to the preparation by the teachers in questioning them as well as questioning skill applying an effective strategy.

Despite of various questions posted by teachers in learning English, there is a lack of teachers' preparations on types of questions in classroom. This may due to routine as a teacher where preparing of verbal questions seem to be not a priority. In addition, in Indonesia context the main focus of teaching English is to ensure students acquire basic skills and for examination purposes. MQS seems to be more relevant for teachers to prepare the school test rather than use them for verbal in English lessons. The issue is not that teachers are not asking questions, it is that they are not posing the types of questions that have been shown to best result in positive students' achievement such as higher order, critical thinking, curious, and problem solving questions (Almeida, 2010; Kim, 2010; Marzano \& Kendall, 2007; Shen, 2012). As context and culture may affect the use of MQSs (DeWaelsche, 2015), a study in the Indonesian EFL context is lacking. Although a bulk of studies on MQSs was conducted globally, research on MQSs in the Indonesian EFL context is limited which calls for a study in this area.

\subsection{Purpose of the Study}

This study aims to identify English teachers' competencies in their knowledge, preparation and questioning skills in enhancing students' English proficiency. The aspects of teachers' knowledge in this study focuses on their knowledge in difficulty level of questions, questioning strategies suitable for students' needs. Meanwhile, for their preparation more refer to types of questions and materials that can improve English learning in the classrooms. As for questioning skills, the aspects are viewed from teachers' variety skills such as designing the questions as well as differentiating higher and lower order level of questions.

\section{Methodology}

This survey study utilizes questionnaire to identify the level of teachers' knowledge, preparation and questioning skills. The questionnaire uses 5 Likert scale point which consists of 8 items for knowledge and 10 items for preparation and questioning skills respectively. The results of pilot study showed that all items in the questionnaire have high reliability level with the Cronbach Alpha value between 0.772 and 0.962. The population of English teachers in this study are 216 from 40 junior high schools in Pekanbaru, Riau Indonesia. Stratified random sampling was applied to choose the sample of this study. This study involved samples from all 40 junior secondary schools in Pekanbaru, Riau Indonesia. The number of English teachers involved in this study was 160 in which 4 teachers were chosen from each school.

\section{Findings and Discussion}

\begin{tabular}{|c|c|c|c|c|}
\hline Item & Aspect & Mean & S.D & Interpretation \\
\hline B1 & $\begin{array}{c}\text { My knowledge on multiple questioning strategies } \\
\text { and techniques in classroom }\end{array}$ & 3.53 & 0.536 & Moderate \\
\hline B2 & $\begin{array}{c}\text { My knowledge on the difficulty level of questions } \\
\text { according to students' ability }\end{array}$ & 3.61 & 0.734 & Moderate \\
\hline
\end{tabular}




\begin{tabular}{|c|c|c|c|c|}
\hline Item & Aspect & Mean & S.D & Interpretation \\
\hline B3 & My knowledge on delivering questions in a very \\
effective way & 3.42 & 0.908 & Moderate \\
\hline B4 & $\begin{array}{c}\text { My knowledge on promoting students' thinking to } \\
\text { guide them in answering the questions }\end{array}$ & 3.90 & 0.799 & High \\
\hline B5 & $\begin{array}{c}\text { My knowledge on students' preferences in current } \\
\text { issues for the purposes of questioning }\end{array}$ & 3.53 & 0.603 & Moderate \\
\hline B6 & $\begin{array}{c}\text { My knowledge on various questioning techniques for } \\
\text { individual, group and whole-class }\end{array}$ & 3.61 & 0.682 & Moderate \\
\hline B7 & $\begin{array}{c}\text { My knowledge on questions that can stimulate } \\
\text { students' critical thinking skills }\end{array}$ & 3.58 & 0.587 & Moderate \\
\hline B8 & $\begin{array}{c}\text { My knowledge on questioning strategies that can } \\
\text { improve students' English skills }\end{array}$ & 3.55 & 0.523 & Moderate \\
\hline & Overall & 3.59 & 0.482 & Moderate \\
\hline
\end{tabular}

Table 1: Level of Knowledge on Multiple Questioning Strategies

Table 1 shows that the overall level for teachers' knowledge is at moderate level. This result illustrates that teachers have yet to possess adequate knowledge and understanding in questioning strategies. In order to enhance students' proficiency in English, teachers should improve their knowledge in multiple questioning strategies. This result is in line with Robitaille \& Maldonado (2015) which noted that it is important for all teachers to have a good understanding of the questioning strategies in teaching language as it encourages students to participate in language learning activities.

\begin{tabular}{|c|c|c|c|c|}
\hline Item & Aspect & Mean & S.D & Interpretation \\
\hline C1 & $\begin{array}{c}\text { Making preparation for questioning activities in } \\
\text { classroom }\end{array}$ & 3.775 & 0.633 & High \\
\hline C2 & $\begin{array}{c}\text { Preparing questions in lesson plans based on } \\
\text { learning objectives }\end{array}$ & 3.700 & 0.716 & High \\
\hline C3 & $\begin{array}{c}\text { Preparing learning materials for questions \& } \\
\text { answers sessions }\end{array}$ & 3.55 & 0.837 & Moderate \\
\hline C4 & $\begin{array}{c}\text { Preparing contents through questions that are } \\
\text { relevant to students }\end{array}$ & 3.55 & 0.837 & Moderate \\
\hline C5 & $\begin{array}{c}\text { Preparing questions that are going to be posted for } \\
\text { individual, group and whole-class }\end{array}$ & 3.56 & 0.829 & Moderate \\
\hline C6 & $\begin{array}{c}\text { Preparing various questiongs to begin the lesson } \\
\text { (induction set) }\end{array}$ & 3.55 & 0.923 & Moderate \\
\hline C7 & $\begin{array}{c}\text { Preparing classroom activities that contain a lot of } \\
\text { questions \& answer session }\end{array}$ & 3.36 & 0.934 & Moderate \\
\hline C8 & Preparing various difficulty level of questions & 3.68 & 0.855 & High \\
\hline C9 & $\begin{array}{c}\text { Preparing various types of questions to encourage } \\
\text { students' critical thinking }\end{array}$ & 3.88 & 0.721 & High \\
\hline C10 & $\begin{array}{c}\text { Preparing questions that are commonly used in } \\
\text { national examination for the purposes of teaching } \\
\text { and learning }\end{array}$ & 3.95 & 0.729 & High \\
\hline & Overall & 3.78 & 0.360 & High \\
\hline
\end{tabular}

Table 2: Level of Preparation in Designing Questions

Table 2 above shows that teachers have a high level of preparation practices in questioning strategies. Results of this study revealed that the lowest element reported by teachers was on the preparation of classroom activities that contain a lot of questions \& answer sessions. This informs that teachers may not realize that classroom activities can motivate students' involvement in question and answer sessions. Vong \& Kaewurai (2017) stated that teachers are supposed to plan classroom activities thoroughly as the activities help them promote positive participation of students particularly in learning English. 


\begin{tabular}{|c|c|c|c|c|}
\hline Item & Aspect & Mean & S.D & Interpretation \\
\hline D1 & $\begin{array}{c}\text { My ability/ skill to use multiple questioning } \\
\text { techniques in classroom }\end{array}$ & 3.61 & 0.560 & Moderate \\
\hline D2 & $\begin{array}{c}\text { My ability to design spontaneous questions that } \\
\text { match with students' needs }\end{array}$ & 3.67 & 0.532 & High \\
\hline D3 & $\begin{array}{c}\text { My ability to differentiate higher and lower- } \\
\text { order level of questions }\end{array}$ & 3.66 & 0.498 & Moderate \\
\hline D4 & $\begin{array}{c}\text { My ability to use numerous English language } \\
\text { styles to encourage students in answering } \\
\text { questions }\end{array}$ & 3.58 & 0.597 & Moderate \\
\hline D5 & $\begin{array}{c}\text { My creativity to design questions to improve } \\
\text { students' participation in English teaching and } \\
\text { learning }\end{array}$ & 3.69 & 0.560 & High \\
\hline D6 & $\begin{array}{c}\text { My ability to design various type of questions } \\
\text { based on learning objectives }\end{array}$ & 3.63 & 0.482 & Moderate \\
\hline D7 & $\begin{array}{c}\text { My ability to practice the communication skills } \\
\text { in questions \& answers session }\end{array}$ & 3.63 & 0.509 & Moderate \\
\hline D8 & $\begin{array}{c}\text { My competency in making use of questions to } \\
\text { evaluate students' ability in the English } \\
\text { language }\end{array}$ & 3.63 & 0.533 & Moderate \\
\hline D9 & $\begin{array}{c}\text { My ability to use various questions for students' } \\
\text { handouts in classroom }\end{array}$ & 3.63 & 0.521 & Moderate \\
\hline D10 & $\begin{array}{c}\text { My ability to involve students' actively in } \\
\text { classroom activities by using various types of } \\
\text { questions } \\
\text { Overall }\end{array}$ & 3.64 & 0.480 & Moderate \\
\hline
\end{tabular}

Table 3: Level of Questioning Skills

Based on table 3 above, it can be seen that the majority teachers in this study believed that they had moderate levels of questioning skills. The only element that was reported to be high was regarding the teachers' creativity to design questions to improve students' participation in English teaching and learning. This shows that teachers believed that they were creative enough in designing questions. Gore et.al (2017) indicated that the teachers have general skill in crating questions.

\section{Contribution/ Implications and Suggestions}

This study identified teachers' preparation as the main factor in the implementation of multiple questioning strategies (MQSs) among English teachers in SMPN Pekanbaru. This shows that teachers require preparation and early planning in designing a variety of questions covering both low-order thinking and higher-order thinking questions according to the level of students' cognitive diversity. By preparing and planning various questions by teachers, the students' English achievement can be improved from time to time. This is line with the study published by the Sun (2012) that stated students' comprehension and achievement in English learning can be improved by providing detailed and comprehensive preparation in multiple questioning that is expected to help students improve their understanding in English. Besides that, proper questioning skills can also trigger students' interest in learning English and at the same time create an interactive environment for classroom learning process.

The current study suggests the review of current teachers training curriculum specially to see effective strategy to integrate the pedagogical knowledge and MQSs application especially for English teachers' training curriculum. As the current study identified the need for MQS in enhancing English language competence, a strategic collaboration between research universities abroad and teachers training institute in Indonesia is highly needed. This is due to the findings from this study revealed that teachers still lack in terms of those aspects. Besides that, distinguished component in reference to questioning strategies should be included in the syllabus of teachers' training especially in the aspects of strategies, types of questions, the difficulty level of questions and questioning reflection. Teachers should pose appropriate questions with the aim of developing critical thinking and problem solving skills in students.

\section{Conclusion}

In general, this study identifies that teachers' competencies in multiple questioning strategies require improvement particularly in terms of knowledge, preparation and questioning skills. There are some aspects that need to be improved in order to enhance students' proficiency in English. For the time being, English teachers are requested to take their own initiatives to improve their skills in designing and developing both low and higher-order thinking questions for fostering critical thinking. Indeed, the school leaders should design a specific programme to train those teachers. Then, the school and English language committee need to be concerned to enhance the knowledge of multiple questioning strategies among English 
teachers through constant workshops or in-service training. This is due to the fact that the multiple questioning strategies will not be able to perform in English classrooms if the teachers do not master the aspects stated.

\section{References}

i. Ariffin, K. (2005). English in Education: Issues and Challenges in The Malaysia Classroom. Shah Alam: Pusat Penerbitan Universiti (Upena) Bahasa Dalam Kalangan Pelajar Tingkatan 2. Jurnal E- Bangi, 3(3), 1-17.

ii. DeWaelsche, S. A (2015). Critical thinking, questioning and student engagement in Korean University English courses. Linguistics and Education. 32, 131-0147.

iii. Gore, J., Lloid, A., Smitrh, M., Bowe, J., Ellis, H., \& Luban, D. (2017). Effects of professional development on the quality of teaching: Results from a randomized controlled trial of quality teaching rounds. Teaching anjd Teacher Education, 68, 99-113.

iv. Hashim, S. \& Yaakub, R. (2003). Psikologi Pembelajaran dan Personaliti. Gombak, Selangor: Pts Publication and Distributors Sdn Bhd.

v. Luaran, J.E. 2013. Pengintegrasian Web 2.0 dalam Pengajaran dan Pembelajaran Subjek Sejarah dan Geografi. Seminar Pendidikan Sejarah dan Geografi (UMS, 29 - 30 Ogos 2013). 16-28

vi. Rabey, G.P. (2001). Motivation Is Response. Industrial and Commercial Training, 33(1). 26-28.

vii. Robitaille, Y.P. \& Maldonado, N. 2015. Teachers' Experiences Relative to Successful Questioning and Discussion Techniques. American International Journal of Contemporary Research. 5(1), 7-16.

viii. Shen, P. \& Yodkhumlue, B. 2012. International Journal of English Linguistics. 2(1). 199-205.

ix. Souriyavongsa, T., Rany, M., Zainol Abidin, M.J. \& Mei, L.L. 2013. Factors Causes Students Low English Language Learning: A Case Study in the National University of Laos. International Journal of English Language Education. 1(1).

x. Sun, Z. (2012). An Empirical Study on New Teacher-Student Relationship and Questioning Strategies in ESL Classroom. English Language Teaching, 5(7), 175-183.

xi. Vong, S. A., \& Kaewurai, W. (2017). Instructional model development to enhance critical thinking and critical thinking ability of trainee students at regional teaching training center in Tokeo province, Cambodia. Kasetsart Journal of Social Science. 38(1), 88-95. 